\title{
PENGELOLAAN LINEN DI PUSKESMAS LUBUK BASUNG KABUPATEN AGAM
}

\author{
R.Firwandri Marza, Deharnita, Syaliati \\ (Poltekkes Kemenkes Padang)
}

\begin{abstract}
Dirty linen is an important source of contamination at the health center. Although the linen is not used directly in the treatment process but its effect can be seen when handling linen not properly managed will lead to disease transmission is through nosocomial infections. The purpose of research is to know the description of washes and linen management processes in PHC Lubuk Basung Agam. The research method is descriptive qualitative approach, because this approach could explore deeply about the picture of the management of linen in Public Health Center of Lubuk Basung that is based on research objectives and principles - the principle of conformity (appropriateness) and sufficiency (adequacy). The total of research informants is sixpeople with in-depth interviews. The results show the different stages of the process of washing dirty linen weight (infectious) are soaked before input into the washing machine but do not use hot water, while the soiled linen mild (non-infectious) was not done soaking, for the washing process using one unit of washing machines and at the same stage should be stored in a closet storage for all kinds of linen in the health center. It is suggested for washing linen officers to pay more attention in the management of soiled linen weight (infectious). Soaking should use hot water and should always use personal protective equipments (PPE) in progress.
\end{abstract}

Keywords : :Management, Linen, health centers,

\section{PENDAHULUAN}

Linen adalah bahan kain yang digunakan di rumah sakit untuk kebutuhan pembungkus kasur, bantal, guling, selimut, baju petugas, baju pasien dan alat instrumen steril lainnya. Jenis linen menurut kontaminasinya ada 2 yaitu linen infeksius dan linen non infeksius. Linen infeksius adalah linen yang terkena cairan tubuh pasien seperti fases, muntah, darah, dan air seni. Linen non infeksius adalah linen yang tidak terkena cairan tubuh manusia. ${ }^{5}$

Laundry tempat pencucian linen di rumah sakit adalah penyumbang limbah cair terbesar yaitu sebanyak $40 \%$ limbah cair yang ada di rumah sakit, sehingga sistem pengelolaan air limbah di rumah sakit harus ektra kerja keras apabila dari pihak laundry tidak mengunakan kimia laundry yang ramah lingkungan. Laundry harus dilengkapi saluran air limbah tertutup yang dilengkapi dengan pengolahan awal (pre-treatment) sebelum dialirkan ke instalasi pengolahan air limbah. ${ }^{6}$

Pengelolaan linen ini harus dilakukan dengan hati-hati supaya tidak terjadi infeksi nosokomial. Infeksi nosokomial ini merupakan jenis infeksi nosokomial lingkungan (environmental infection) yang mana infeksi ini disebabkan oleh kuman yang berasal dari benda atau bahan tak bernyawa seperti linen di lingkungan rumah sakit. ${ }^{10}$

Berdasarkan penelitian terdahulu oleh Dian Sri Siswanti pada petugas laundry di Rumah Sakit Telogorejo kota Semarang, ditemukan para petugas laundry menderita penyakit kulit dermatitis yang dapat dilihat pada kaki dan tangan petugas setelah melakukan pencucian linen 
menjadi merah-merah dan gatal-gatal sehingga membuat petugas menjadi tidak nyaman dan akan mengganggu pekerjaannya.

Berdasarkan penelitian terdahulu oleh Eskariana Nugraheni dan Surahma Asti Mulasari yang dilakukan di Rumah Sakit X di Yogyakarta ditemukan pada proses pencucian linen kotor infeksius dan non infeksius tidak dipisahkan, pada proses pencucian menggunakan mesin cuci yang sama. Akibatnya memungkinkan adanya infeksi karena salah satu faktor yang menimbulkan terjadinya infeksi adalah adanya yang terkontaminasi.

Untuk mencegah infeksi nosokomial pada pasien dan penyakit dermatitis kontak iritan pada petugas laundry perlu dilakukan perlakuan tepat dalam proses pengelolaan linen, pada proses pengumpulan perlunya pemisahan antara linen infeksius dan non infeksius, proses pengangkutan, proses pencucian seperti pengeringan serta penyetrikaan, penyimpanan dan pendistribusianperlunya petugas memakai Alat pelindung diri(APD). ${ }^{6}$

Berdasarkan survei pengamatan awal yang dilakukan, Puskesmas Lubuk Basung sebagai salah satu Puskesmas rawat inapyang memiliki jumlah tempat tidur sebanyak 8 tempat tidur serta memilki ruangan khusus untuk pengelolaan linen, ruangan ini digunakan untuk mencuci semua linen yang ada di Puskesmas,pada proses pencucian linen petugas laundry linen tidak menggunakann alat pelindung diri (APD), pada saat pencucian tidak dipisah antara linen infeksius dan non infeksius, laundry pencucian linen juga tidak memilki kran air panas, proses pengangkutan linen bersih juga tidak menggunakan kereta dorong khusus yang tertutup dan di ruangan pencucian pencahayaan yang kurang.

\section{METODE PENELITIAN}

Penelitian ini bersifat deskriptif dengan pendekatan kualitatif, di laksanakan di Puskesmas Lubuk Basung, Kecamatan Lubuk Basung Kabupaten Agam pada bulan Januari s/d Juni tahun 2016. Informan berjumlah 6 orang yang terdiri dari pengelola petugas linen 2 orang, sanitasi 1 orang petugas sanitarian, penanggung jawab Puskesmas 1 orang (Pimpinan Puskesmas), 1 orang Ka.TU (Ketua Tata Usaha) dan informan dari poli rawat inap 1 orang penanggung jawab poli rawat inap. Alat yang digunakan untuk pengumpulan data dalam penelitian adalah pedoman wawancara, alat pencatat, alat pengukur kebisingan (soundlevel meter), alat mengukur suhu (termometer), alat mengukur pencahayaan (lux meter), alat perekam suara(tape recorder) dan panduan penelusuran pengamatan(check list)untuk pemeriksaan dalam pengamatan. Data diperoleh dengan melakukan wawancara menggunakan panduan wawancara mendalam (in-depth interview) dan pemeriksaan. Uji validasi (triangulasi) meliputi : Triangulasi sumber dan Triangulasi metode. Analisis data dilakukan dengan analisis isi. (content analysis). 


\section{HASIL PENELITIAN}

\section{Gambaran Tempat Pengelolaan Linen di Puskesmas Lubuk Basung}

Ruang pencucian linen di Puskesmas Lubuk basung sudah tersedia kran untuk air bersih, sedangkan penyediaan untuk air panas dengan suhu $75^{\circ} \mathrm{C}$ dalam waktu 25 menit atau $95^{\circ} \mathrm{C}$ dalam waktu 10 menit sebagai desinfektan belum bisa dilengkapi, akan tetapi untuk penyediaan desinfektan jenis lain sudah tersedia contohnya bahan pembersih noda. Penyataan ini juga disampaikan oleh informan 5 yaitu “....untuk kain yang terkena darah biasanya direndam terlebih dahulu dengan menggunakan (merek dagang) ..."

Puskesmas Lubuk Basung sudah memiliki mesin cuci dan peralatan untuk pencucian, akan tetapi belum tersedia mesin cuci yang dapat mencuci jenis linen yang berbeda, dan peralatan cuci juga tidak dipasang permanen juga tidak diletakan didekat dengan saluran pembuangan air limbah sedangkan untuk pengelolaan saluran air limbah menggunakan sistem tertutup yang terhubung dengan paralon, tapi untuk pengelolaan awal ( pre-treatment) belum dilakukan sebelum dialirkan ke instalasi pengelolaan air limbah. Pernyataan ini sesuai dengan yang disampaikan oleh informan 1 yaitu:“...karena keterbatasan sumber daya maka belum bisa...mesin cuci hanya tersedia satu unit, sebenarnya alat cuci atau alat laundry itu dipisah,..."Ruang linen di Puskesmas Lubuk Basung hanya terdiri dari satu ruangan saja belum ada disediakan ruangan terpisah ynag sesuai dengan kegunaannya, untuk pencahayaan di ruangan linen sudah cukup terang akan tetapi karena suara mesin pada saat proses pencucian, dan pengeringan terdengar kuat.

\section{Gambaran Proses Pengelolaan Linen di Puskesmas Lubuk Basung}

Proses pengelolaan linen di Puskesmas Lubuk Basung dibawah pengawasan tenaga sanitarian, pencucian linen kotor dapat dibedakan menjadi 2 bagian yaitu, pencucian linen kotor berat (infeksius) dan pencucian linen kotor ringan (non infeksius). Proses pengelolaan linen mulai dari tahap pengumpulan sampai tahap penyimpanan dilakukan langsung di Puskesmas Lubuk Basung tidak ada kerjasama dengan pihak luar.

\section{a. Tahap Pengumpulan}

Pada tahapan pengumpulan linen kotor dikumpulkan pada masing - masing ruangan dan diangkut oleh petugas linen ataupun staf yang piket ke ruang pencucian linen. Linen kotor dikumpul sudah menggunakan ember yang tertutup dan sudah dilakukan pemisahan antara linen infeksius dan non infeksius.

\section{b. Tahap Penerimaan}

Pada tahap penerimaan linen kotor yang dibawa dari masing - masing ruangan diterima oleh petugas laundry yang bekerja atau yang bertanggung jawab pada shiff waktu tersebut, dan dilakukan pencatatan dan perhitungan linen, akan tetapi tidak dilakukan pemilahan linen sesuai dengan tingkat kekotorannya. 


\section{c. Tahap Pencucian}

Proses pencucian linen belum dilakukan penimbangan sebelum dimasukan kedalam mesin cuci, proses pencucian menggunakan mesin cuci, sedangkan perlakuan pencucian manual menggunakan tangan biasanya hanya untuk kain pel dan sudah dilakukan perendaman terhadap kain yang terkena darah (infeksius) sebelum pencucian, dilakukan oleh 2 orang petugas laundry yang masing - masing dibagi menjadi 2 shiff ( pagi dan sore). Pernyataan ini juga disampaikan oleh informan 4 yaitu“ ... pencucian secara manual menggunakan tangan biasanya hanya pada kain pel, untuk kain linen yang terkena darah biasanya direndam diluar terlebih dahulu setelah itu dimasukan kedalam mesin cuci..."

Pada tahapan pencucian tidak ada dilakukan perendaman menggunakan air panas dan petugas juga tidak menggunakan APD, padahal APD sudah disediakan, hal ini dikerenakan kurangnya pengawasan dari tenaga sanitarian dan tingkat kepatuhan petugas yang kurang. Pernyataan ini juga ditegaskan oleh informan 1 : “....sebenarnya alat cuci atau alat laundry itu dipisah, dan cara perlakuan yang berbeda, akan tapi yang baru bisa kita lakukan yaitu penyediaan alat pelindung diri, tapi perlakuan cuci dengan air panas belum bisa dilakukan... tetapi tingkat kepatuhan petugas juga kurang.."

\section{d. Tahap Penyimpanan}

Pada tahapan penyimpanan linen bersih disimpan dilemari khusus untuk linen yang memiliki pintu dan tertutup serta bebas dari serangga, akan tetapi tidak dilakukan pemisahan sesuai dengan jenisnya pernyataan ini juga disampaikan oleh informan 5 dan dan informan lainnya yaitu "...linen yang sudah bersih di simpan dilemari dekat ruang rawat inap dan dilakukan pencatatan, disimpan didalam satu lemari, pemisahan hanya bertuliskan kain rawat inap, kain petugas...penyusunan linen dengan sistem linen baru dibagian bawah, linen lama diangkat keatas.."

\section{e. Tahap Pendistribusian}

Pada tahap untuk pendistribusian linen yang sudah bersih diantar dari ruang linen ke masing-masing ruangan, seperti linen untuk rang rawat inap di antar ke ruang rawat inap begitu juga dengan linen untuk IGD. Linen yang sudah bersih dibawa menggunakan keranjang yang tidak tertutup dan dalam pendistribusian juga tidak menggunakan kartu tanda terima dari petugas, akan tetapi sudah dilakukan sterilisasi sebatas untuk linen diruang persalinan, dalam pembawaan linen bersih dan linen kotor sudah terpisah. Pernyataan ini disampaikan oleh informan 5 dan ditegaskan oleh informan 1 yaitu “...untuk membawa linen bersih menggunakan keranjang... steril baru sebatas di ruang persalinan,..."

\section{f. Tahap Pengangkutan}

Pada tahap akhir untuk pengangkutan linen yang sudah bersih diangkut menggunakan keranjang yang terpisah dengan tempat untuk pengangkutan linen kotor yang menggunakan ember. Pernyataan ini juga disampaikan oleh petugas laundry (informan 5 dan 6) dan juga ditegaskan oleh informan 1 yaitu“...untuk pengangkutan linen kotor digunakan baskom yang 
ditutup dipisah dengan linen yang bersih pengangkutannya menggunakan keranjang ...perlakukannya berbeda mulai dari membawa dan pintu masuk juga bebeda, karena keterbatasan sumber daya maka belum bisa..."

\section{Pencucian linen kotor berat (Infeksius)}

Proses pencucian linen kotor berat di Puskesmas Lubuk Basung yaitu mulai dari tahap penerimaan dari sumber linen kotor yang berasal dari ruang rawat inap, ruang IGD, ruang poli KIA dan ruang paska persalinan. Pernyataan ini disampaikan oleh beberapa informan yaitu“...linen kotor bersumber dari BP umum, ruang KIA, rawatan... ....linen kotor selain dari ruang rawatan juga berasal dari poli...linen berasal dari ruang rawat inap, ruang petugas, ruang dokter jaga dan ruang bayi BGM..."

Pada tahap pengangkutan linen kotor dari sumber diangkut ke ruang pencucian linen oleh petugas linen atau staf yang piket pada masing-masing ruangan dengan menggunakan ember yang di tutup. Pernyaaan ini sesuai dengan penyataan yang disampaikan oleh semua informan“...linen kotor dikumpuklan oleh petugas linen langsung, yang diambil dari masingmasing ruangan, kadang - kadang linen kotor langsung diantar oleh petugas piket dari masing-masing ruangan serta langsung dilakukan pemilahan dan diangkut menggunakan ember..."

Pada tahap pencucian petugas linen melakukan perendaman terlebih dahulu, untuk linen yang terkena darah merendamnya terlebih dahulu, seperti yang disebutkan oleh informan 4 dan informan lainnya yaitu “...untuk kain linen yang terkena darah biasanya direndam diluar terlebih dahulu setelah itu dimasukan kedalam mesin cuci... ...kain yang berdarah dipisah dalam pencuciannya tetapi kain yang kotor ringan tidak, kalau kain berdarah dicuci atau direndam diluar dahulu setelah itu langsung masuk dalam mesin cuci..."

Pada tahap pencucian dan penambahan detergen oleh petugas linen, setelah memasukan linen kedalam mesin cuci dan ditambahkan air, setelah itu petugas linen menembahkan deterjen untuk proses pencucian, lama waktu pencucian sekitas 30 menit,seperti yang disampaikan oleh informan 6 dan didukung oleh pernyataan dari informan lainnya yaitu “...pencucian menggunakan detergen khusus dengan mesin cuci dan pembilasan ditambahkan softener..."Pada tahap pengeringan linen dan penyetrikaan, linen dikeringkan langsung menggunakan mesin pengering pada mesin cuci dan dilanjutkan dengan dijemur dengan cahaya matahari dan setelah itu disetrika, pernyataan ini diperkuat oleh pernyataan informan 5 dan 6 yaitu“...Pengeringan langsung dengan mesin cuci, lalu langsung di jemur di bawah sinar matahari dan disetrika... ...meskipun pengeringan menggunakan mesin, tepi juga dijemur dengan matahari setelah itu disertika diruangan laundy.."

Pada tahap akhir untuk penyimpanan linen yang sudah bersih dan rapi disimpan dilemari penyimpanan linen yang tertutup yang terletak di ruangan rawat inap, keterangan ini juga disampaikan oleh informan 4 bagian penanggung jawab rawat inap dan di betulkan oleh informan lainnya yaitu“...setelah disetrika linen yang sudah bersih disimpan dilemari

Penerbit: Poltekkes Kemenkes Padang, http://jurnal.poltekkespadang.ac.id/ojs/index.php/jsm 
penyimpanan yang ada di ruang rawat inap..untuk pengangkutannya yaitu menggunakan keranjang yaitu kain yang sudah rapi... untuk penyimpanan di simpan di lemari pada ruang rawat inap, hal ini untuk memudahkan petugas staf rawat inap..."

Berikut ini adalah bagan tahapan pencucian linen kotor berat (infeksius) di Puskesmas Lubuk Basung :

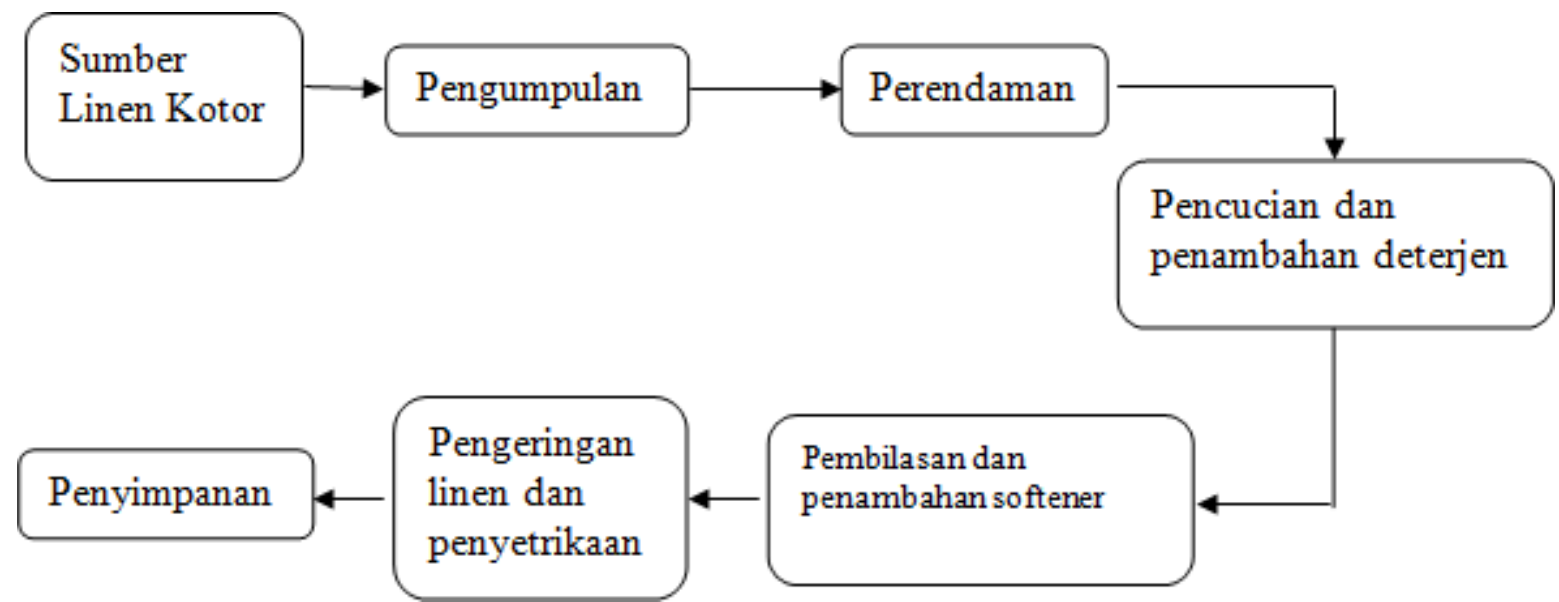

Bagan 1. Tahap pencucian linen kotor berat (infeksius)

\section{Proses pencucian linen kotor ringan (non infeksius)}

Proses pencucian linen kotor ringan (non infeksius) seperti gorden pintu, serbet, pakaian petugas, seprai dari kamar jaga petugas, kain pel, dan kain lap dari dapur gizi yang ada di Puskesmas Lubuk Basung di cuci di ruang linen di mulai dari petugas linen mengumpulkan linen dari ruangan - ruangan sumber linen kotor yang berasal dari ruang rawat inap, ruang IGD, ruang poli KIA, kamar jaga petugas, dapur dan ruang pasca persalinan di angkut ke ruang pencucian linen menggunakan ember yang tertutup.

Petugas linen memasukan linen kedalam mesin cuci dan menambahakan air dan detergen. Lama waktu pencucian sekitar 15 menit, lalu dilakukan pembilasan dan penambahan softener, setelah itu pengeringan dilakukan oleh petugas menggunakan mesin pengering langsung dengan mesin cuci dan di jemur di bawah sinar matahari dan yang terakhir dilakukan penyetrikaan dan disimpan dilemari penyimpanan.Perbedaan proses pencucian linen kotor ringan (non infeksius) dengan linen kotor berat (infeksius) hanya terletak pada proses perendaman saja, seperti yang di sampaikan oleh salah satu informan yaitu“ ...kain yang berdarah dipisah dalam pencuciannya tetapi kain yang kotor ringan tidak, kalau kain berdarah dicuci atau direndam diluar dahulu setelah itu langsung masuk dalam mesin cuci...pencucian menggunakan detergen khusus denganmesin cuci dan pembilasan ditambahkan softener..."

Berikut adalah bagan tahapan pencucian linen kotor ringan (non infeksius) di Puskesmas Lubuk Basung : 


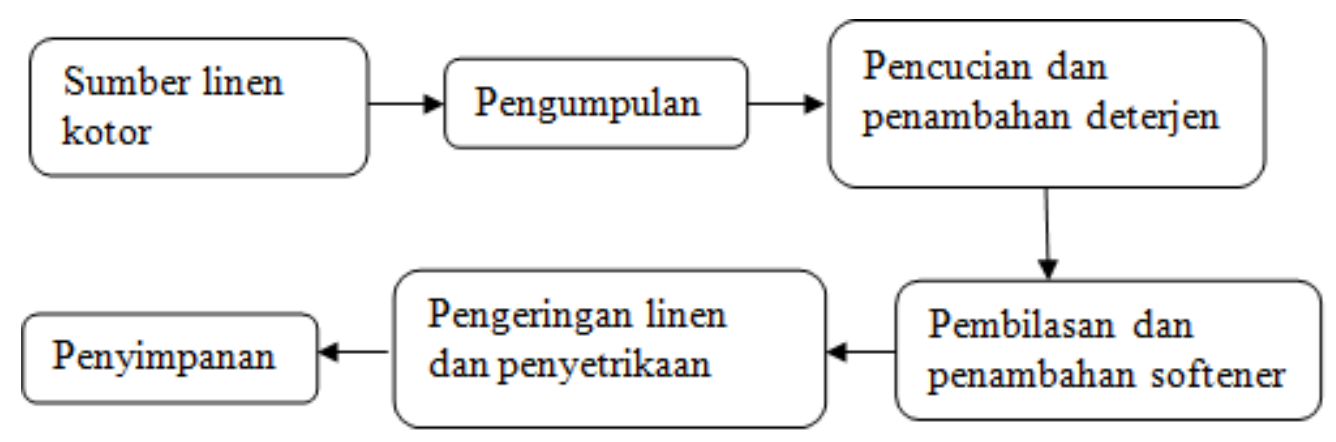

Bagan 2. Tahap pencucian linen kotor ringan (non infeksius)

\section{PEMBAHASAN}

Puskesmas Lubuk Basung merupakan Puskesmas Rawat Inap dengan 8 tempat tidur untuk ruang rawat inap ( 4 tempat tidur rawat inap laki - laki dan 4 tempat tidur ruang inap perempuan).Puskesmas Lubuk Basung memiliki ruang cuci linen sendiri, tidak ada kerja sama dengan pihak lain. Proses pengelolaan linen di Puskesmas Lubuk Basung di mulai dari tahap pengumpulan linen kotor dari berbagai sumber seperti ruang rawat inap, ruang KIA, ruang pasca bersalin, IGD, dan poli klinik oleh petugas linen maupun staf yang bertanggung jawab pada masing- masing ruangan yang langsung di bawa ke ruang cuci linen, linen-linen tersebut kemudian di sortir, dihitung berdasarkan jenisnya dan kemudian dilakukan pencatatan. Setelah dilakukan pencatatan, linen kemudian masuk dalam tahap pencucian.

\section{Tempat Pengeloaan Linen di Puskesmas Lubuk Basung}

Laundry rumah sakit adalah tempat pencucian linen yang dilengkapi dengan sarana penunjangnya berupa mesin cuci, alat dan desinfektan, mesin uap (steam boiler), pegering, meja dan meja setrika. ${ }^{12}$ Pelayanan linen pada hakikatnya adalah tindakan penunjang medik yang dilaksanakan dengan sebaik - baiknya dan bertanggung jawab untuk membantu unit unit lain di rumah sakit yang membutuhkan linen yang siap pakai. ${ }^{5}$

Hasil observasi yang dilakukan pada ruang linen di Puskesmas Lubuk Basung di ketahui bahwa belum tersedianya air panas untuk desinfektan dan peralatan cuci yang dipasang permanen dan diletakan dekat dengan saluran pembuangan air limbah. Menurut Kepmenkes RI No.1204 Tahun 2004 pada tempat pengelolaan linen tersedia air panas dengan suhu $75^{\circ} \mathrm{C}$ dalam waktu 25 menit atau $95^{\circ} \mathrm{C}$ dalam waktu 10 menit dan peralatan cuci juga dipasang permanen dan diletakan dekat dengan saluran pembuangan air limbah.

Program ruangan minimal pada Puskesmas rawat inap salah satunya yaitu memiliki ruangan cuci linen, untuk tingkat pencahayaan direkomendasikan sebesar 100 Lux dan untuk kebisingan di ruang cuci linen yaitu sebesar $45 \mathrm{~dB} .^{3}$ Ruangan cuci linen di Puskesmas Lubuk Basung memiliki pencahayan yang sudah memenuhi persyratan yaitu sebesar 110.4 Lux, sesuai dengan Peraturan Menteri Kesehatan RI Nomor : 75 tahun 2014, sedangkan untuk kebisingan 58,2 dB belum memenuhi persyaratan. Proses pencucian linen kotor karena hanya memiliki satu mesin cuci maka tidak ada dikakukan pemisahan untuk pencucian linen kotor 
berat (infeksius) dengan linen kotor ringan (non infeksius), hal ini dikarenakan keterbatasan sumberdaya dan dana untuk menunjang terlaksananya proses sebagaimana mestinya, serta masih kurangnya perhatian dari instansi pemerintah tentang kelengkapan sarana dan prasarana yang diperlukan untuk Puskesmas rawat Inap seperti ini.

Berdasarkan penelitian terdahulu Eskariana Nugraini dan Surahma Asti Mulasari yang dilakukan dirumah sakit $\mathrm{X}$ yokyakarta ditemukan pada proses pencucian linen kotor infeksius dan non infeksius tidak dipisahan, dan pada proses pencucian juga menggunakan mesin cuci yang sama. Akibatnya adanya infeksi karena salah satu faktor yang menimbulkan terjadinya infeksi adalah adanya yang terkontaminasi. ${ }^{18}$

\section{Proses Pengelolaan Linen di Puskesmas Lubuk Basung}

a. Tahap Penerimaan

Pada tahap penerimaan linen kotor di Puskesmas Lubuk Basung, pada proses pengumpulan linen kotor tidak dikumpulkan dalam ember atau container yang tertutup.

Menurut Kepmenkes RI No.1204 Tahun 2004 pada tahapan penerimaan linen kotor harus dikumpulkan didalam kantong plastik atau container yang tertutup.

\section{b. Tahap Pencucian}

Pada tahap pencucian linen kotor di Puskesmas Lubuk Basung masih belum dilakukan penimbangan berat linen sebelum dimasukan kedalam mesin cuci dan dalam pencucian juga tidak dilakukan pencuciannya berdasarkan tingkata kekotorannya. Menurut Kepmenkes RI No.1204 Tahun 2004 pada tahapan pencucian sebelum linen dimasukan kedalam mesin cuci harus dilakukan penimbangan terlebih dahulu dan untuk proses pencucian harus berdasarkan tingkat kekotorannya.

\section{c. Tahap Penyimpanan}

Pada tahap penyimpanan tidak adanya penyimpanan linen sesuai dengan kegunaannya, penyimpanan semua linen bersih di Puskesmas Lubuk Basung digabung kedalam 1 lemari. Menurut Kepmenkes RI No.1204 Tahun 2004 pada tahapan penyimpanan seharusnya dilakukan pemisahan linen sesuai dengan jenis dan kegunaannya.

\section{d. Tahap Pendistribusian.}

Pada tahap pengangkutan linen bersih di Puskesmas Lubuk Basung hanya menggunakan keranjang yang terbuka juga tidak menggunakan trolli/kereta dorong yang sudah steril dan tidak adanya pendistribusian berdasarkan kartu tanda terima dari petugas linen kepada pihak perawatan. Menurut Kepmenkes RI No.1204 Tahun 2004 pada tahapan pendistribusian linen yang sudah bersih harus tertutup saat dibawa keruang perawatan, dibawa menggunakan kereta dorong/trolli yang sudah steril dan dilakukan pendistribusian linen berdasarkan kartu tanda terima dari petugas.

\section{e. Tahap Pengangkutan}

Pada tahap penggkutan linen di Puskesmas Lubuk Basung hanya menggunakan ember, karena keterbatasan sumberdaya tidak ada penyediaan kereta dorong, akan tetapi ada 
pemisahan antara wadah untuk pengangkutan linen bersih dan linen kotor. Menurut Kepmenkes RI No.1204 Tahun 2004 pada tahapan penggkutan harus menggunakan kereta dorong yang berbeda dan tertutup antara linen bersih dan linen kotor.

\section{Proses Pencucian Linen Kotor Berat ( Infeksius )}

Linen infeksius ( linen kotonr berat) adalah linen yang terkena cairan tubuh pasien seperti fases, muntah, darah, dan air seni. ${ }^{5}$ Proses pencucian linen kotor berat (infeksius) di mulai dari tahap pengumpulan linen dari sumber, pencatatan dan dilakukan perendaman, pencucian dan penambahan deterjen, pembilasan dan penambahan softener, pengeringan, penyetrikaan dan penyimpanan di lemari penyimpanan.

Pada tahap pengumpulan dilakukan penyortiran antara linen kotor berat dengan linen kotor ringan, ini dimaksutkan untuk menghindari kontaminasi paada saat pencucian,akan tetapi petugas linen tidak menggunakan APD dalam proses pengerjaan, setelah itu dilakukan pencatan linen yang akan dicuci, kemudian linen direndam terlebih dahulu menggunakan pada ember khusus yang berisi campuran bahan desinfektan dan air panas yang berguna untuk menetralkan linen yang terkontaminasi.

Tahap selanjutnya yaitu tahap pencucian menggunakan mesin cuci yang hanya berkapasitas $5 \mathrm{Kg}$ dengan penambahan deterjen khusus dengan mesin cuci, proses ini berlangsung 30 menit.Tahap selanjutnya yaitu dilakukan pembilasan menggunakan air bersih dan penambahan softener, yang bertujuan agar sisa-sisa deterjen hilang dan membuat pakaian bersih dan wangi.

Proses pengeringan dengan mesin pengering yang langsung pada mesin cuci yang sama, setelah itu di jemur dibawah sinar matahari dan yang teakhir yaitu proses penyetrikaan dan penyimpanan pada satu lemari penyimpanan untuk semua jenis linen.

Berdasarkan penelitian terdahulu oleh Cristian Indrawati yang dilakukaan di Rumah Sakit Islam Cilacap ditemukan bahwa mekanisme proses pengelolaan linen masih ada yang belum terlaksana dengan baik yaitu proses penyimpanan linen bersih belum dipisahkan sesuai jenisnya dan pintu lemari belum keadaan tertutup. ${ }^{24}$

\section{Proses Pencucian Linen Kotor Ringan ( Non Infeksius )}

Linen non infeksius (linen kotor ringan) adalah linen yang tidak terkena atau terkontaminasi oleh darah, cairan tubuh, dan fases yang berasal dari pasien lainnya secara rutin, meskipun mungkin linen yang diklasifikasikan dari seluruh pasien berasal dari sumber ruang isolasi yang terinfeksi. ${ }^{5}$

Proses pencucian linen kotor ringan (non infeksius) hampir sama dengan proses pencucian linen kotor berat (infeksius). Perbedaan dari pencucian tersebut hanya pada proses penghilangan noda dan lama pada proses pencucian. Untuk linen kotor berat (infeksius) dilakukan perendaman terlebih dahulu sebelum di cuci sedangkan untuk linen kotor ringan (non infeksius) tidak dilakukan perendaman, setelah dilakukan pencatatan langsung dilakukan proses pencucian. Waktu pencucian linen berbeda tergantung dari jenis linen yang dicuci, 
misalnya untuk linen kotor ringan dilakukan selama 15 menit sedangkan untuk linen kotor berat dilakukan selama 30 menit.

Permasalahan dari pengelolaan tempat pencucian linen di ruang linen Puskesmas Lubuk Basung pada keterbatasan alat yaitu kurangnya jumlah mesin cuci, jumlah mesin cuci hanya ada 1 unit, misalnya untuk pencucian linen kotor berat (infeksius) harusnya dipisah dengan pencucian linen kotor ringan (non infeksius).

Akibat dari penggunaan mesin cuci yang sama bisa memungkinkan adanya infeksi karena salah satu faktor yang menimbulkan terjadinya infeksi menurut Depkes RI (2004) adalah penggunaan alat yang terkontaminasi. ${ }^{5}$

\section{SIMPULAN DAN SARAN}

Penelitian menunjukan perbedaan tahapan proses pencucian linen kotor berat (infeksius) yang direndam terlebih dahulu sebelum dimasukan kedalam mesin cuci akan tetapi tidak menggunakan air panas, sedangkan linen kotor ringan (non infeksius) tidak dilakukan perendaman, untuk proses pencucian menggunakan 1 unit mesin cuci yang sama dan pada tahap penyimpanan disimpan dalam 1 lemari untuk semua jenis linen yang ada di Puskesmas.Disarankan bagi petugas pencucian linen agar lebih memperhatikan pengelolaan linen kotor berat (infeksius). Perendaman sebaiknya menggunakan air panas dan sebaiknya selalu menggunakan alat pelindung diri (APD) dalam proses pengerjaan.

\section{DAFTAR PUSTAKA}

1. Depkes RI. Rencana Pembangunan Kesehatan Menuju Indonesia Sehat 2015. Jakarta; 2000

2. UU RI No.36 Tahun 2009 Tentang Kesehatan. Jakarta ; 2009

3. Peraturan Menteri Kesehatan RI. No. 75 Tahun 2014 Tentang Pusat Kesehatan Masyarakat. Jakarta; 2014

4. Depkes RI. Standar Pelayanan Minimal Kesehatan di Kabupaten/Kota. Jakarta ;2003

5. Depkes RI. Pedoman Manajemen Linen di Rumah Sakit. Jakarta; 2004

6. Joko,Heru.2009. Hospital Laundry.Jakarta.[diakses 13 Desember 2015].Tersedia dari :URL. http://heroedjokohospitallaundry.blogspot.co.id/

7. Alamsyah, dedi dan ratna muliawati. Pilar Dasar Ilmu Kesehatan Masyarakat. Yogyakarta: Nuha Medika; 2013

8. PERDA. Profil Kesehatan Provinsi Sumatera Barat Tahun 2015. Padang ;2016

9. PERDA. Profil Pembangunan Kesehatan Kabupaten Agam tahun 2011. Lubuk Basung; 2012 
10. Rohani dan Setio Hingawati. Panduan Praktik Keperawatan Nosokomial. Klaten: PT Intan Sejati; 2010

11. Tietjen,Linda dan Debora Bowemeyer. Panduan Pencegahan Infeksi untuk Fasilitas Pelayanan Kesehatan dengan Sumber Daya Terbatas. Jakarta : Yayasan bina pustaka sarwono prawiharojo; 2004

12. Kepmenkes RI. No. 1204 Tahun 2004 Tentang Persyaratan Kesehatan Lingkungan Rumah Sakit. Jakarta; 2004

13. Depkes RI.Standar Kesehatan dan Keselamatan Kerja. Jakarta .2009

14. Ferdian, Hengki. 2011. Dermatitis Kontak Iritan Pada Petugas Laundry Rumah Sakit (Study Kasus Pengelolaan Penyakit Akibat Kerja). Jakarta. [diakses 09 Desember 2015]. Tersedia dari : URL http://www.slideshare.net/hengkiferdianto/dermatitis kontak-iritan-padapetugaslaundry- rumah-sakit.

15. Satrianegara, M. Fais. Buku Ajar Organisasi dan Manajemen Pelayanan Kesehatan serta Kebidanan. Jakarta : Salemba Medika, Dasar dasar Manajemen; 2009

16. Kemenkes RI. Profil Kesehatan Indonesia tahun 2014. Jakarta; 2015.

17. Nurlely,Ika apriani.2015.Pengolahan Linen Rumah Sakit.Jakarta.[diakses13 Desember 2015].Tersedia dari :URL http://ikaapriani2804.blogspot.com/2014/09/pengolahan-linenrumah-sakit.html

18. Nugraheni,Eskariana dan Surahma Asti Mulasari.2013. Analisis Tingkat Kepatuhan Petugas Linen Laundry Terhadap SOP Pencucian Linen Laundry di rumah Sakit $X$ di Yogyakarta tahun 2013.Yogyakarta .[diakses 09 Desember 2015].Tersedia dari :URLjournal.respati.ac.id/index.php/medika/article/viewFile/105/101

19. Bhaktianti,Yunita Sari. 2008. Study Pengelolaan Linen di RSUD Tugurejo Semarang. Semarang. [diakses 19 Desember 2015]. Tersedia dari :URL http://eprints.dinus.ac.id/7365/

20. Huda, Nurul. 2008. Analisis Pengelolaan Linen Rawat Inap di Unit Laundry RSUD Koja Jakarta. Jakarta. [diakses 07 Desember 2015]. Tersedia:URL http://lib.ui.ac.id/opac/ui/detail.jsp?id=78766\&lokasi=lokal

21. Maleong,Lexy J. Metodologi Penelitian Kualitatif. Bandung. PT Remaja Rosdakarya;2012

22. Siswanti, Dian sri.2012. Proses Pengelolaan Linen Sebagai Salah Satu Risiko Terjadinya Penyakit Kulit Dermatitis Kontak Iritan (Studi Pada Petugas Laundry Di RS TELOGOREJO Kota Semarang Tahun 2011). Semarang .[ diakses 07 Desember 2015].Tersedia ;URL http://lib.unnes.ac.id/15936/

23. Inrawati, Cristian. 2014. Study Pengeloaan Linen di Rumah Sakit Islam Fatimah Cilacap tahun 2012. Semarang. [ diakses 07 Juni 2016]. Tersedia ; URL http:// study-pengelolaanlinen-di-rumah-sakit.html 
Capernito (1995) Rencana Asuhan dan Dokumentasi Keperawatan Edisi 2 EGC Jakarta Garnadi,Yudi.(2012). Hidup Nyaman dengan Diabetes. Jakarta: Agromedia Pustaka Hariyati. (2008). Evaluasi Model Perencanaan Pulang yang Berbasis Teknologi Informasi Volume 12, Makara Kesehatan, Jakarta

.Notoatmodjo, Soekidjo. (2005). Promosi Kesehatan Teori dan Aplikasi, Rineka Cipta, Jakarta.

Potter P.A \& Perry A.G. (2005). Fundamental Keperawatan Volume 1. Alih Bahasa: Yasmin Asih et al. Edisi 7. Jakarta: EGC.

Untari T. (2010). Hubungan Pengetahuan dengan Pelaksanaan Discharge Planning oleh Perawat di RSUD Wates Kulon Progo Yogyakarta. Belum dipublikasikan.

Setyowati T. (2011). Pelaksanaan Discharge Planning oleh Perawat Pada Pasien di Ruang Syaraf dan Bedah Syaraf Gedung Kemuning Rumah Sakit Umum Pusat dr. Hasan Sadikin Bandung. 2011 